back last week by accusing the study of having being conducted by "interested parties... predominantly representing the business community". But although several panel members have a business affiliation, the national security panel is also well represented. Allen was formerly chief of staff of the Air Force, and the panel included several other defence luminaries, not least Admiral Bobby Inman, another former director of the National Security Agency who was one of the first government officials to voice concern about the "haemorrhaging" of Western technology to the Eastern bloc.

The Pentagon had already showed its contempt for the study in February 1986, when it withdrew its cooperation after liaison was switched from the Pentagon's department of research and engineering to its policy-making division. It then refused to pay the second of two agreed $\$ 100,000$ contributions towards the cost of the study. A Pentagon spokesman said the decision was taken because the study was not producing new information or practical recommendations, and pointed out that no other government agency (such as the Commerce Department, criticized in the study for being ineffective) had provided more than the Department of Defense (DoD) contribution.

Perle's thesis is that tighter controls are necessary because many Soviet military advances have demonstrably led straight from technology acquired illicitly from the West. Allen's report does not dispute the premise, but argues that current regulations impose trade barriers on many items that, although militarily useful, can easily be acquired from third countries. The Pentagon weakened its case by failing to provide data in support of its estimates of the cost to the West of Soviet acquisition of Western technology.

The other side of the coin is trade: because of the complexity of the US export licensing system and the uncertainty and delay it engenders, US industry complains it is losing orders to overseas suppliers. Allen's panel, which was able to analyse the Department of Commerce's administration of export licence applications, concluded that such self-imposed trade barriers threaten US - and the West's technology advantage over the Soviet Union by stiffling innovation. Despite some attempts recently by the Commerce Department to be more responsive to industry's needs, DoD still exercises a veto which in practice causes frequent delays for companies wanting to export to certain countries. By restricting US exports, the panel found US regulations are encouraging the growth of overseas sources for socalled "dual use" items with military and civilian applications.

The solution the Allen panel proposes is to strengthen CoCom and to limit controls to truly critical items. One of the problems of the present unilateral US control system is that there is no effective way of removing items from the "control list" once they have been put on it - and it apparently includes almost every modern industrial process. The Allen panel suggested that developing countries with rapidly growing technological capabilities be encouraged to institute "CoComlike" procedures.

Allen's panel expresses concern about several recent moves by DoD which place under tighter control technical information arising from its research projects, even when such information is not classified. The panel is particularly concerned about the impact of such new control schemes on professional societies' meetings; it believes the benefits of open dissemination of research data outweigh possible risks.

Some observers believe that, as a practical matter, Allen's report, already publicly dismissed by DoD, will have no effect on bringing about change in US policy. But others, including some Capitol Hill staff, are not so pessimistic. There is, they point out, likely to be much interest in US economic competitiveness in the 100th Congress, and far-reaching trade legislation is on the agenda. The research council's study may yet pay off. Tim Beardsley

\title{
UK long-term public spending plans turn the clock back 20 years
}

\section{London}

THE British government intends further to reduce the amount of public spending, in proportion to national income, over the next three years and to demand greater value for money from its investments, including scientific research. Researchers on government projects will receive a modest increase in funds in the next year - in the run-up to a general election but the rate of growth will be quickly curtailed in the following year. Public spending in $1987-88$ and $1988-89$ will be $£ 148.6$ and $£ 154.2$ thousand million, respectively, with a new spending limit of $£ 161.5$ thousand million set for the following year. By the end of the decade, if the plan is not altered, Britain will have turned the clock back nearly twenty years on public spending.

Specifically, what this means is that the budgets of most spending agencies, measured in strictly cash terms, are likely to increase more quickly this year than next, at least on present plans. Thus the total budget of the research councils, dependencies of the Department of Education and Science, are to increase by about 6 per cent between this year and next (beginning 1 April), but then by only two per cent in the succeeding year. Much the same applies to the budget of the University Grants Committee, although the planned reduction between 1987 and 1988 will not be so sharp.

The government has made little secret in recent years of its discomfort about the level of public expenditure. Its investment in scientific research, about $£ 4.3$ thousand million a year, is under threat as government pushes for industrial investment in research and attempts to transfer the results of research, particularly in defence, to the commercial sector. The Ministry of Defence consumes about half of the publicly funded research cake. The mood at the Natural Environment Research Council, which published its annual report almost simultaneously with the government's expenditure plans last week, reflects that pressure. The council, which has agents around the world and conducts much work for industrial/commercial clients, intends to create its own commercial subsidiary to sell and exploit the products of its research.

Previous attempts to exploit British research commercially have depended on the creation of new bodies to help steer the research towards the commercial sector. The National Enterprise Board (NEB) and the National Research Development Corporation (NRDC) were two such bodies set up by previous administrations, the former taking substantial equity stakes in manufacturing and high technology industries.

The present government had a different approach and demanded more industrial participation and a reduction in government expenditure. It inherited NEB and NRDC, and merged them into the British Technology Group, ensuring that major government shareholdings were sold. Although the logic behind the new expenditure figures is consistent with previous government thinking, no attempt has been made to address the issues outlined in two major science plans now before ministers. The first, presented at the end of last year by a committee headed by retired Glaxo chairman Sir Austin Bide, called for about $£ 500$ million of public money to be invested in industry and scientific research, which in turn would attract the same from industry.

The second is the British 15-year space plan, presented to government last summer in anticipation of a positive response in November. The plan calls for an additional $£ 200$ million a year for space research and development - twice the current figure.

Neither plan has received a response and both were ignored in last week's budget disclosures.

Bill Johnstone 